\title{
Effects of serum and insulin-like growth factors on human neuroblastoma cell growth
}

\author{
Mihir A. Meghani, Donna M. Martin, J. Robinson Singleton and Eva L. Feldman \\ Department of Neurology and the Neuroscience Program, The University of Michigan, Ann Arbor, MI (USA)
}

(Received 18 March 1993; revised version received and accepted 6 March 1993)

Key words: Insulin-like growth factor; mRNA; Proliferation; Serum; Antibody; SH-SY5Y

\section{Summary}

Insulin-like growth factors (IGF-I and IGF-II) are mitogenic polypeptides expressed in both developing and adult tissues. To examine the effects of IGFs on neuronal growth, we used SH-SY5Y neuroblastoma cells as an in vitro model of nervous system development. In the current study, we found that either IGF-I $(0.1$ to $10 \mathrm{nM})$, insulin $(0.1$ to $5 \mu \mathrm{g} / \mathrm{ml})$ or calf serum $(0.1$ to $3 \%)$ increased SH-SY5Y proliferation over a 3 day period in a dose dependent manner. In each case, treatment with anti-IGF-I receptor antibodies blocked cell proliferation. IGF-II mRNA levels correlated with SH-SY5Y cell density; subconfluent cells expressed high levels of IGF-II mRNA while low levels of IGF-II mRNA were present in confluent cells. Similarly, serum deprivation increased IGF-I receptor mRNA by 4-fold. Collectively, these results support the concept that an IGF/IGF-I receptor system at least partially mediates SH-SY5Y cell proliferation and suggests the importance of IGFs in regulating neuronal growth.

\section{Introduction}

The insulin-like growth factors (IGF-I and IGFII) belong to a family of polypeptides which promotes neuronal growth and survival [1]. During development, high levels of IGF transcripts are present

Correspondence to: E.L. Feldman, $1120 \mathrm{C}$ Neuroscience Laboratory, 1103 E. Huron Avenue, Ann Arbor, MI 48104, USA. in the mammalian nervous system [2]. IGF-II can stimulate DNA synthesis and proliferation in fetal neuroblasts [3-5] and both IGF-I and IGF-II promote survival as well as vigorous neuritic outgrowth of cultured chick sensory and sympathetic neurons [4]. Like other polypeptides, effects of the IGFs are mediated through binding to specific receptors. The IGF-I receptor, with a strong homology to the insulin receptor, is a tetrameric protein with intrinsic tyrosine-kinase activity [6]. The IGF-II/mannose 
6-phosphate (IGF-II/M6P) receptor has a unique monomeric structure with distinct binding sites for IGF-II and M6P and is responsible for lysosomal enzyme trafficking [7]. The growth promoting effects of the IGFs are mediated primarily via the IGF-I receptor [8-10]. The role of the IGF-II/M6P receptor in IGF signal transduction is less clear [8].

Cloned SH-SY5Y neuroblastoma cells, believed to have arisen from neural crest cells [11], provide a good model system for examining the growth promoting effects of IGFs. These cells express IGF-II but not IGF-I mRNA [12] and possess functional IGF receptors [13-15]. We have reported that SHSY5Y cells undergo density dependent autocrine growth, and, within $24 \mathrm{~h}$ of serum deprivation, express increased levels of IGF-II mRNA followed by secretion of immunoreactive IGF-II protein [16]. Exogenous addition of IGF II enhances SH-SY5Y growth, while treatment with anti-IGF-II antibody or anti-IGF-I receptor antibody $\left(\alpha-\mathrm{IR}_{3}\right)$ partially blocks autocrine growth $[16,17]$.

In the current study, we have extended our inital observations on the regulation of SH-SY5Y growth. We report that insulin and IGF-I increase SH-SY5Y proliferation via the IGF-I receptor, and that this receptor partially mediates calf serum-stimulated growth. Furthermore, expression of the IGF-II and IGF-I receptor genes exhibit serum and density dependence. Our results provide further evidence that neuroblastoma cell growth is mediated via an IGF/ IGF-I receptor system. This work extends our knowledge of IGF growth-promoting mechanisms, and indicates that insulin and IGFs are important in autocrine and serum-stimulated neuroblastoma cell growth.

\section{Materials and Methods}

Cell culture flasks were purchased from Corning Glass Works (Corning, NY), and Costar (Cambridge, MA). Calf serum (CS) and Dulbecco's modified Eagle's medium (DMEM) were obtained from
Gibco BRL (Gaithersburg, MD). Restriction enzymes were from Boehringer-Mannheim (Indianapolis, IN) and Gibco BRL. Polyclonal IgG against human IGF-I receptor $\left(\alpha-\mathrm{IR}_{3}\right)$ was obtained from Oncogene Science (Uniondale, NY). IGF-I was purchased from Bachem (Torrance, CA). All other chemicals were purchased from Sigma Chemical Company (St. Louis, MO).

\section{Cell culture}

SH-SY5Y human neuroblastoma cells were generously provided by Dr. Stephen Fisher, University of Michigan Medical Center. Cells were subcultured in $75 \mathrm{~cm}^{2}$ culture flasks in DMEM and $10 \% \mathrm{CS}$, and maintained at $37^{\circ} \mathrm{C}$ in a humidified atmosphere with $10 \% \mathrm{CO}_{2}$. The medium was changed every $2-3$ days.

\section{Cell proliferation assay}

Cells were washed twice with DMEM and plated at a density of $9 \cdot 10^{4}$ cells $/ \mathrm{cm}^{2}$ in 96 -well plates in $100 \mu \mathrm{l}$ DMEM with or without CS, $1 \mu \mathrm{g} / \mathrm{ml} \alpha-\mathrm{IR}_{3}$, IGF-I $(0.1,1,3$, and $10 \mathrm{nM})$, or insulin $(0.1,1,3$, and $5 \mu \mathrm{g} / \mathrm{ml})$. Cell proliferation was measured by using the MTT colorimetric assay as previously described $[16,18]$. At each time point, $25 \mu \mathrm{l}$ of MTT $(3(4,5-$ dimethylthiazol-2-yl)-2,5-diphenyltetrazolium bromide) was added $(1 \mathrm{mg} / \mathrm{ml})$ for a $2 \mathrm{~h}$ incubation at $37^{\circ} \mathrm{C}$ in a humidified atmosphere with $10 \% \mathrm{CO}_{2}$. Next, $100 \mu \mathrm{l}$ lysis buffer $(0.1 \mathrm{ml}$ of $50 \%$ dimethyl formamide, $20 \%(\mathrm{w} / \mathrm{v}) \mathrm{SDS}, \mathrm{pH} 4.7)$ was added and the cells were incubated in the dark overnight. The absorbance $(A)$ of each well was measured at a wavelength of $570-595 \mathrm{~nm}$ by a Bio-Rad Model 2550 EIA reader (Bio-Rad Laboratories, Melville, NY).

\section{Northern analysis and $c D N A$ probes}

SH-SY5Y cells were plated $\left((2-16) \cdot 10^{4}\right.$ cells $/ \mathrm{cm}^{2}$ in T150 flasks) in DMEM and 10\% CS and grown for 2 days. The medium was then removed, the cells were washed twice in DMEM, and DMEM with or without $10 \%$ CS was added. RNA was extracted 
either immediately (no media change) or 1,2 , or 3 days after this medium change. Northern analysis was performed as previously reported [12]. RNA $(20 \mu \mathrm{g})$ was electrophoresed in formaldehydeagarose gels and transferred to Nytran membranes (Schleicher and Schuell, Keene, NH) and then successively hybridized with $\left[{ }^{32} \mathrm{P}\right] \mathrm{dCTP}$ labeled $\left((0.1-10) \cdot 10^{8} \mathrm{cpm} / \mu \mathrm{g}\right) \mathrm{cDNA}$ probes for either the human IGF-I receptor (bases 1490-2737 encoding the $\alpha$ and $\beta$ chains were excised with $E c o$ RI and Hind III) [19] or human IGF-II (bases 1-854 of a cDNA encoding exons 7,8 , and part of 9 excised with $P s t \mathrm{I})$ [20], and chicken $\beta$-actin $(1.8 \mathrm{~kb}$ was excised with Pst I) [21]. Densitometry was done and the relative $A$ for each hybridization was calculated by averaging several exposures that were within the linear range of the film. These values were expressed as a percentage of untreated (day 0 ) controls and were then divided by a percentage of control values similarly obtained for $\beta$-actin hybridizations.

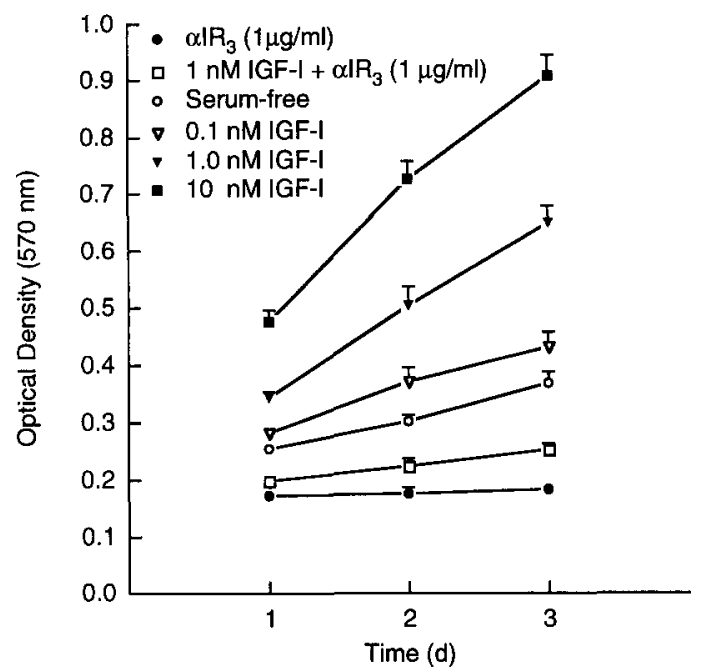

Fig. 1. Effects of IGF-I and IGF-I receptor antibody on SHSY5Y cell proliferation. SH-SY5Y cells were washed with DMEM and plated at a density of $9 \cdot 10^{4}$ cells $/ \mathrm{cm}^{2}$ in 96 -wells with or without $\alpha-\mathrm{IR}_{3}$ at $1 \mu \mathrm{g} / \mathrm{ml}$ or various concentrations of IGF-I, as indicated in the legend. Cell number was measured after 1,2 , or 3 days using the MTT assay, as described in Materials and Methods. Values represented are the means of $7-8$ wells \pm S.E.M. from a representative experiment performed twice.

\section{Results}

\section{Effects of IGF-I and insulin on cell proliferation}

To examine the effects of IGF-I and insulin on SH-SY5Y proliferation, cells were plated in DMEM with and without IGF-I $(0.1,1,3,10 \mathrm{nM})$ or insulin $(0.1,1,3,5 \mu \mathrm{g} / \mathrm{ml})$. In the presence of either IGF-I or insulin, the cells divided in a dose-dependent fashion between days 1-3 (Figs. 1 and 2). The maximal effects were with either $10 \mathrm{nM}$ IGF-I (Fig. 1) or 5 $\mu \mathrm{g} / \mathrm{ml}$ insulin (Fig. 2) throughout the 3 days. The addition of the IGF-I receptor antibody, $\alpha-\mathrm{IR}_{3}$, blocked both IGF-I and insulin-mediated cellular proliferation (Figs. 1 and 2), suggesting that both polypeptides stimulate growth via the IGF-I receptor.

\section{Serum stimulated cell proliferation}

We then examined serum regulated SH-SY5Y proliferation by growing cells in increasing concentrations of calf serum. Cell proliferation exhibited a

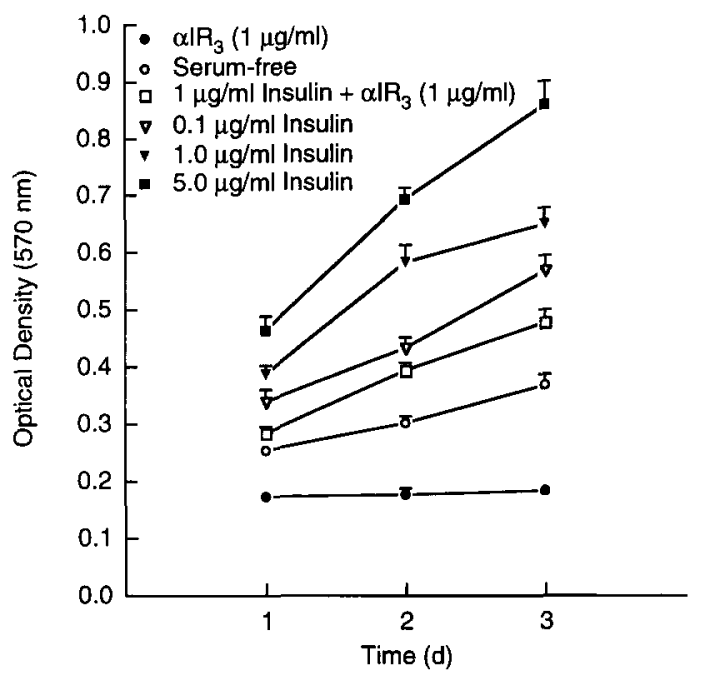

Fig. 2. Effects of insulin and IGF-I receptor antibody on SHSY5Y cell proliferation. SH-SY5Y cells were washed with DMEM and plated at a density of $9 \cdot 10^{4}$ cells $/ \mathrm{cm}^{2}$ in 96 -wells with or without $\alpha-\mathrm{IR}_{3}$ at $1 \mu \mathrm{g} / \mathrm{ml}$ or various concentrations of insulin, as indicated in the legend. Cell number was measured after 1,2 , or 3 days using the MTT assay, as described in Materials and Methods. Values represented are the means of 8 wells \pm S.E.M. from a representative experiment performed twice. 

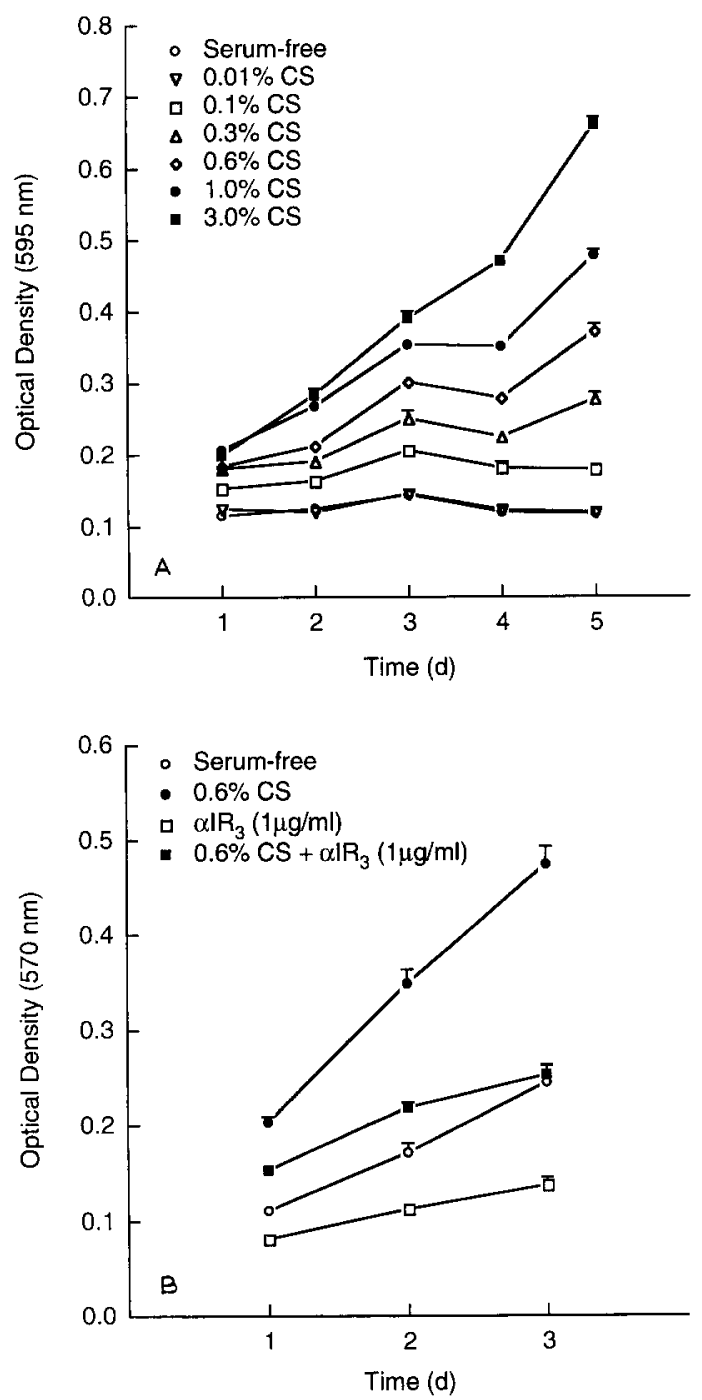

Fig. 3. (A) Effects of serum on SH-SY5Y cell proliferation. SHSY5Y cells were washed with DMEM and plated in 96-wells at a density of $6 \cdot 10^{4}$ cells $/ \mathrm{cm}^{2}$ in various concentrations of calf serum (CS), as indicated in the legend. Cell number was measured on each of 5 days using the MTT assay. Values represented are the means of 8 wells \pm S.E.M. from a representative experiment performed three times. (B) Effects of IGF-I receptor antibody and serum on SH-SY5Y cell proliferation. SH-SY5Y cells were washed with DMEM and plated in 96-wells at a density of $9 \cdot 10^{4}$ cells $/ \mathrm{cm}^{2}$ in serum or serum-free media, with or without $\alpha-\mathrm{IR}_{3}(1$ $\mu \mathrm{g} / \mathrm{ml})$, as indicated in the legend. Cell number was measured after 1,2 , or 3 days using the MTT assay, as described in the methods. Values represented are the means of 8 wells \pm S.E.M. from a representative experiment performed twice. serum dose-dependent response, i.e., higher concentrations of serum were correlated with higher numbers of cells (Fig. 3A). To determine what fraction of serum-stimulated growth was mediated via the IGF-I receptor, $\mathrm{SH}-\mathrm{SY} 5 \mathrm{Y}$ cells were grown in $0.6 \% \mathrm{CS}$ in the presence of the IGF-I receptor blocking antibody, $\alpha-\mathrm{IR}_{3} . \alpha-\mathrm{IR}_{3}$ completely blocked serum-free growth and, as early as day $1, \alpha-\mathrm{IR}_{3}$ inhibited cell proliferation when compared to serum-containing media alone (Fig. 3B). However, unlike its effects on serum-free growth, $\alpha$-IR $\mathrm{R}_{3}$ did not completely block cell proliferation in the presence of serum (Fig. 3B).

\section{$I G F-I I$ and IGF-I receptor gene expression}

We have previously reported that SH-SY5Y cells express three IGF-II transcripts, $1.8,4.8$ and $6.0 \mathrm{~kb}$

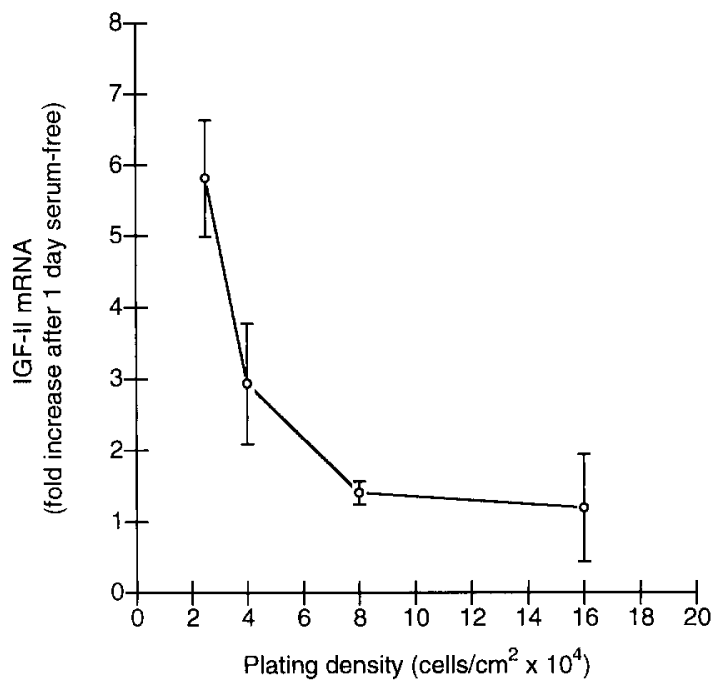

Fig. 4. Density dependence of increased IGF-II mRNA. SHSY5Y cells were plated in paired flasks at $(2-16) \cdot 10^{4}$ cells $/ \mathrm{cm}^{2}$ (as indicated on the $\mathrm{X}$-axis) in DMEM $+10 \%$ calf serum and allowed to grow for two days. RNA was then isolated from one flask of cells at each density. The other flasks were rinsed three times and treated with serum-free DMEM, then cultured for an additional $24 \mathrm{~h}$, at which time RNA was isolated. Northern analysis of total RNA was performed, using $\left[{ }^{32} \mathrm{P}\right] \mathrm{cDNA}$ probes for IGF-II and $\beta$-actin. Relative optical densities are expressed on the $\mathrm{Y}$-axis as fold increase relative to day 0 for each specific density, normalized to $\beta$-actin relative absorbances. Values are from one of two experiments with similar results 


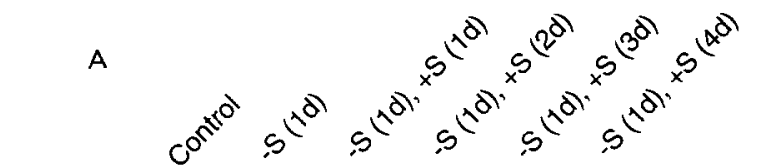

Type I receptor

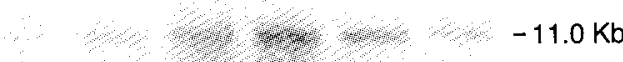

$\beta$-actin
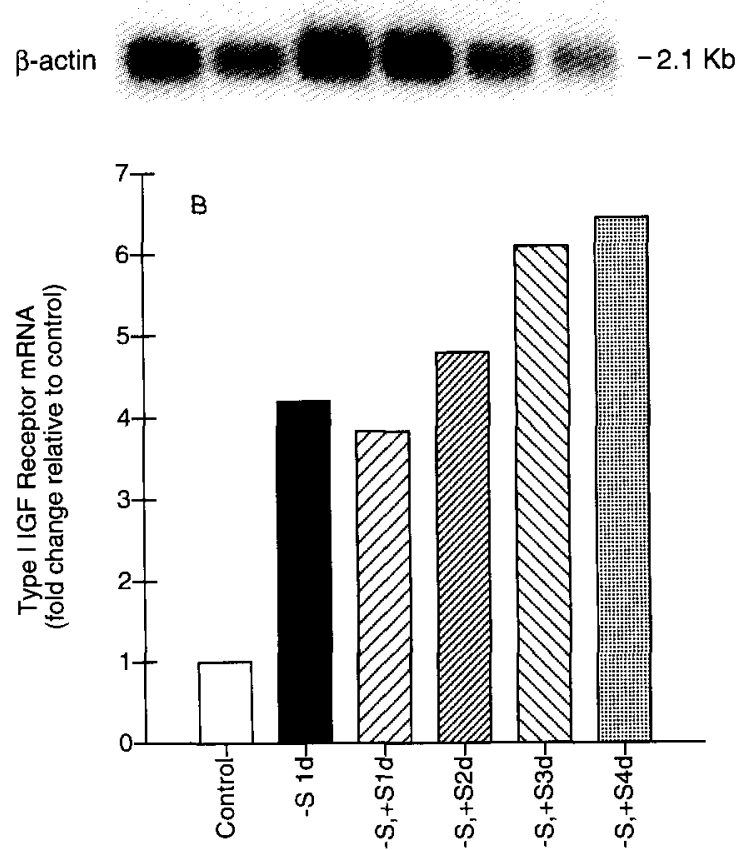

Fig. 5. Northern analysis of IGF-I receptor mRNA. SH-SY5Y cells were plated in $6 \mathrm{~T} 150$ flasks at $3.7 \cdot 10^{4} \mathrm{cells} / \mathrm{cm}^{2}$ in DMEM $+10 \%$ calf serum and allowed to grow for 2 days. RNA was then isolated from one flask (control) and the other flasks were rinsed three times with DMEM, and $20 \mathrm{ml}$ fresh DMEM added. RNA was then isolated after 1 day (serum-free 1 day) or the medium removed and $20 \mathrm{ml} \mathrm{DMEM}+10 \%$ calf serum added. RNA was then isolated from the remaining flasks after 1, 2, 3 or 4 days (serum-free 1 day, + serum 1, 2, 3 or 4 days). Northern analysis of total RNA was performed, using $\left[{ }^{32} \mathrm{P}\right] \mathrm{cDNA}$ probes for IGF-I receptor and $\beta$-actin. A representative autoradiograph from one of two experiments is shown in (a). Transcript sizes in kilobases are indicated at the right. Autoradiographs exposed $4 \mathrm{~h}$ (IGF-I receptor) and $36 \mathrm{~h}$ ( $\beta$-actin). In (b), densitometric analysis was perfomed on the $11.0 \mathrm{~kb}$ IGF-I receptor and $2.1 \mathrm{~kb} \beta$-actin mRNA bands of the autoradiograph shown in (a). IGF-I receptor mRNA $A$ is expressed on the Y-axis as fold increase relative to control, normalized to $\beta$-actin. Each bar corresponds to the lanes in part (a). in length [12]. In the current study, we analyzed the most abundant transcript, the $6.0 \mathrm{~kb}$, as a representative measure of total IGF-II content. As previously reported [16], IGF-II mRNA levels increased by 6-fold within $24 \mathrm{~h}$ after serum removal. We then determined the effects of cell density on IGF-II mRNA levels as shown in Fig. 4. At the lowest density used $\left(2.5 \cdot 10^{4}\right.$ cells $/ \mathrm{cm}^{2}$, subconfluency), IGF-II mRNA increased 6-fold above untreated control. This effect was reduced at higher plating densities (4 or $8 \cdot 10^{4}$ cells $/ \mathrm{cm}^{2}$ ), and there was no increase in IGF-II mRNA content at the highest density employed $\left(16 \cdot 10^{4}\right.$ cells $/ \mathrm{cm}^{2}$, confluency). Thus, IGF-II mRNA increases after 1 day in serum-free media, but only at low (subconfluent) cell densities.

As previously reported, Northern analysis of total cellular RNA detected an $11 \mathrm{~kb}$ IGF-I receptor mRNA transcript [12]. We then tested the effects of serum removal on IGF-I receptor mRNA levels (Fig. 5). For these experiments, cells were grown in serum for 2 days, then serum deprived for 1 day, followed by addition of serum for 1, 2, 3 or 4 days. $24 \mathrm{~h}$ of serum deprivation increased the expression of IGF-I receptor mRNA by 4-fold (Fig. 5). Addition of serum to cells which had been initially serum deprived produced a mild, but consistent increase of IGF-I receptor mRNA compared to IGF-I receptor mRNA levels after 1 day of serum deprivation (Fig. 5). The highest level of IGF-I receptor mRNA was detected after 1 day in serum-free media and then 4 days in serum (Fig. 5).

\section{Discussion}

We have previously shown that IGF-II mediates an autocrine growth loop in SH-SY5Y cells via the IGF-I receptor [17]. Serum deprivation increases SH-SY5Y production of IGF-II immunoreactive protein and mRNA [16]. Likewise, SH-SY5Y proliferation is stimulated by addition of exogenous IGF-II [16] and blocked by antibodies to IGF-II or the IGF-I receptor $[16,17]$. In the current study, we 
have extended our observations on IGF-mediated SH-SY5Y growth by examining the growth-promoting effects of IGF-I and insulin.

Both IGF-I and insulin stimulated SH-SY5Y proliferation in a dose-dependent fashion. These effects were blocked by the antibody to the IGF-I receptor, suggesting that this receptor mediates the effects of IGF-I and insulin on SH-SY5Y proliferation. In agreement with our results, IGF-I has been shown to stimulate DNA synthesis and/or cell proliferation in primary neuronal [22] and oligodendrocyte cultures [23], rat sympathetic neuroblasts [5] and two other neuroblastoma cell lines, rat B104 neuroblastoma cells [24] and human SK-N-AS neuroblastoma cells [10]. Similarly, insulin also acts as a mitogen and can increase DNA synthesis in fibroblasts [25-27], mammary tumor [28] and human colon cancer cell lines [29]. Ishii and colleagues reported that insulin increased $\left[{ }^{3} \mathrm{H}\right.$ ] thymidine uptake in SH-SY5Y cells [30] and, independent of cellular proliferation, insulin and IGF-I stimulated neuritic outgrowth [30-32] and selectively enhanced neurofilament [33] and tubulin mRNA [34].

In the present study, IGF-I-, insulin- and calf serum-stimulated increases in cell proliferation were mediated via the IGF-I receptor. These data support the concept that the growth-promoting effects of the IGFs and insulin occur primarily via the IGF-I receptor [8]. We found that only high concentrations of insulin stimulated SH-SY5Y cell proliferation. Similar results have been reported when insulin is used as a mitogen in non-neural cells [25-27] or when insulin is used as a component of chemically defined media [35], implying insulin is acting via the IGF-I receptor. Similarly, as we have observed in SH-SY5Y cells [17] and El-Badry and colleagues in SK-N-AS neuroblastoma cells [10], IGF-II-stimulated neuroblastoma cell growth is also mediated via the IGF-I receptor. Collectively, these data suggest that cell proliferation can at least partially be mediated via an IGF/IGF-I receptor system. Interestingly, $\alpha-\mathrm{IR}_{3}$ did not completely inhibit serumstimulated growth, supporting the concept that other mitogenic factors may be involved in SH-SY5Y cell growth [17]. Preliminary work from our laboratory indicates that epidermal growth factor (EGF) is at least one of the other mitogens involved in SH-SY5Y growth [36].

We have previously speculated that IGF-II expression is up-regulated when SH-SY5Y cells are subconfluent and, conversely, down-regulated when cells reach confluency [16]. Such a pattern of IGF-II expression would suggest a feedback control mechanism on cell growth by factors in SH-SY5Y conditioned media. In support of this idea, we have recently reported that addition of serum to subconfluent cells can decrease IGF-II gene expression [37] In the present study, we observed an inverse relationship between IGF-II mRNA expression and cellular density. After serum removal, subconfluent cells expressed high levels of IGF-II mRNA, while confluent cells expressed lower IGF-II mRNA levels. We propose that factors in the conditioned media of confluent cells, similar to factors present in serum [16,37], regulate an IGF/IGF-I receptor feedback control mechanism. One likely regulatory factor is IGF-II itself [16], although further work is needed to confirm this speculation.

To further characterize the role of a potential IGF/ IGF-I receptor feedback mechanism on SH-SY5Y growth, we examined IGF-I receptor gene expression after serum deprivation and with serum supplementation. We speculated that, in parallel with IGF-II mRNA [16], IGF-I receptor mRNA would be regulated by changes in serum concentrations. As previously observed [17], we saw a 4-fold increase in IGF-I receptor mRNA after one day of serum deprivation. Similarly, we have also observed an increase in IGF-I receptor mRNA when cells were growth inhibited [38]. With serum addition, there was a small but consistent increase in IGF-I receptor mRNA. These results imply that IGF-I receptor gene expression, like IGF-II, is linked to cell proliferation. Subconfluent (i.e., serum-deprived) SH-SY5Y cells increased IGF-I receptor mRNA. The addition of serum allowed cells to approach confluency via 
IGF-I receptor mediated growth; thus, the expression of IGF-I receptor mRNA remained constant or slightly increased. Our findings are consistent with studies showing increased IGF-I receptor mRNA in phorbol ester-treated SH-SY5Y cells $[39,40]$ and suggest that IGF-I receptor gene expression is regulated by cell growth $[17,41,42]$.

In conclusion, our results support the concept that an IGF/IGF-I receptor system at least partially mediates SH-SY5Y cell proliferation. SH-SY5Y cell growth was stimulated by serum, insulin and IGF-I via the IGF-I receptor, which, like IGF-II, exhibited density and serum dependent gene expression. Collectively, our data suggest the importance of IGFs in regulating nervous system growth.

\section{Acknowledgements}

We would like to thank Dr. Douglas Greene for helpful discussions and Judy Kiger for excellent secretarial assistance. Drs. Graeme Bell, Don Cleveland and Axel Ulrich provided the cDNA probes. M.A.M. and D.M.M. were supported by NIH training grant NS07222-09 and E.L.F. by NIH grant NS01380.

\section{References}

1 Rotwein, P., Structure, evolution, expression and regulation of insulin-like growth factors I and II, Growth Factors, 5 (1991) 3-18.

2 Sara, V.R., Hall, K., Insulin-Like Growth Factors and Their Binding Proteins, Physiol. Rev., 70 (1990) 591-614.

3 Bothwell, M., Insulin and somatomedin MSA promote nerve growth factor-independent neurite formation by cultured chick dorsal root ganglionic sensory neurons, J. Neurosci. Res., 8 (1982) 225-231.

4 Recio-Pinto, E., Rechler, M.M., Ishii, D.N., Effects of insulin, insulin-like growth factor-II, and nerve growth factor on neurite formation and survival in cultured sympathetic and sensory neurons, J. Neurosci., 6 (1986) 1211-1219.

5 DiCicco-Bloom, E., Black, I.B., Insulin growth factors regulate the mitotic cycle in cultured rat sympathetic neuroblasts, Proc. Natl. Acad. Sci. USA, 85 (1988) 4066-4070.

6 Morgan, D.O., Jarnagin, K., Roth, R.A., Purification and characterization of the receptor for insulin-like growth factor I, Biochemistry, 25 (1986) 5560-5564.

7 Morgan, D.O., Edman, J.C., Standring, D.N., Fried, V.A., Smith, M.C., Roth, R.A., Rutter, W.J., Insulin-like growth factor II receptor as a multifunctional binding protein, Nature, 329 (1987) 301-307.

8 Czech, M.P., Signal transmission by the insulin-like growth factors, Cell, 59 (1989) 235-238.

$9 \mathrm{Yu}, \mathrm{K}-\mathrm{T}$., Czech, M.P., The type I insulin-like growth factor receptor mediates the rapid effects of multiplication-stimulating activity on membrane transport systems in rat soleus muscle, J. Biol. Chem., 259 (1984) 3090-3096.

10 El-Badry, O.M., Romanus, J.A., Helman, L.J., Cooper, M.J., Rechler, M.M., Israel, M.A., Autonomous growth of a human neuroblastoma cell line is mediated by insulin-like growth factor II, J. Clin. Invest., 84 (1989) 829-839.

11 Biedler, J.L., Roffler-Tarlov, S., Schachner, M., Freedman, L.S., Multiple neurotransmitter synthesis by human neuroblastoma cell lines and clones, Cancer Res., 38 (1978) 37513757.

12 Martin, D.M., Yee, D., Carlson, R.O., Feldman, E.L., Gene expression of the insulin-like growth factors and their receptors in human neuroblastoma cells, Mol. Brain Res., 15 (1992) 241-246.

13 Recio-Pinto, E., Ishii, D.N., Insulin and insulinlike growth factor receptors regulating neurite formation in cultured human neuroblastoma cells, J. Neurosci. Res., 19 (1988) 312-320.

14 Mattsson, M.E.K., Enberg, G., Ruusala, A., Hall, K., Påhlman, S., Mitogenic response of human SH-SY5Y neuroblastoma cells to insulin-like growth factor I and II is dependent on the stage of differentiation, J. Cell Biol., 102 (1986) 19491954.

15 Feldman, E.L., Randolph, A.E., Mannose 6-phosphate potentiates insulin-like growth factor II effects in cultured human neuroblastoma cells, Brain Res., 562 (1991) 111-116.

16 Martin, D.M., Feldman, E.L., Regulation of insulin-like growth factor-II expression and its role in autocrine growth of human neuroblastoma cells, J. Cell. Physiol., (1993) in press.

17 Martin, D.M., Singleton, J.R., Meghani, M.A., Feldman, E.L., IGF receptor function and regulation in autocrine human neuroblastoma cell growth, Regul. Pept., 48 (1993), this issue.

18 Hansen, M.B., Nielsen, S.E., Berg, K., Re-examination and further development of a precise and rapid dye method for measuring cell growth/cell kill, J. Immunol. Methods, 119 (1989) 203-210.

19 Ullrich, A., Gray, A., Tam, A.W., Yang-Feng, T., Le Bon, T., Kathuria, S., Chen, E., Jacobs, S., Francke, U., Ramachandran, J,, Fujita-Yamaguchi, Y., Insulin-like growth factor I receptor primary structure: comparison with insulin receptor suggests structural determinants that define functional specificity, EMBO J., 5 (1986) 2503-2512. 
20 Bell, G.I., Merryweather, J.P., Sanchez-Pescador, R., Stempien, M.M., Priestley, L., Scott, J., Rall, L.B., Sequence of a cDNA clone encoding human preproinsulin-like growth factor II, Nature, 310 (1984) 775-777.

21 Cleveland, D.W., Lopata, M.A., MacDonald, R.J., Cowan, N.J., Rutter, W.J., Kirschner, M.W., Number and evolutionary conservation of a- and b-tubulin and cytoplasmic b- and g-actin genes using specific cloned cDNA probes, Cell, 20 (1980) 95-105.

22 Shemer, J., Raizada, M.K., Masters, B.A., Ota, A., LeRoith, D., Insulin-like growth factor I receptors in neuronal and glial cells: characterization and biological effects in primary culture, J. Biol. Chem., 262 (1987) 7693-7699.

23 McMorris, F.A., Smith, T.M., DeSalvo, S., Furlanetto, R.W., Insulin-like growth factor $\mathrm{I} /$ somatomedin $\mathrm{C}$ : a potent inducer of oligodendrocyte development, Proc. Natl. Acad. Sci. USA, 83 (1986) 822-826.

24 Orlowski, C.C., Chernausek, S.D., Akeson, R., Actions of insulin-like growth factor-I on the B104 neuronal cell line: effects on cell replication, receptor characteristics, and influence of secreted binding protein on ligand binding, J. Cell. Physiol., 139 (1989) 469-476.

25 Conover, C.A., Hintz, R.L., Rosenfeld, R.G., Comparative effects of somatomedin $\mathrm{C}$ and insulin on the metabolism and growth of cultured human fibroblasts, J. Cell. Physiol., 122 (1985) 133.

26 Flier, J.S., Usher, P., Moses, A.C., Monoclonal antibody to the type I insulin-like growth factor (IGF-I) receptor blocks IGF-I receptor-mediated DNA synthesis: clarification of the mitogenic mechanisms of IGF-I and insulin in human skin fibroblasts, Proc. Natl. Acad. Sci. USA, 93 (1986) 664.

27 Furlanetto, R.W., DiCarlo, J.N., Wisehart, C., The type II insulin-like growth factor receptor does not mediate deoxyribonucleic acid synthesis in human fibroblasts, J. Clin. Endocrinol. Metab., 64 (1987) 1142.

28 VanDerBurg, B., Rutteman, G.R., Blankenstein, M.A., DeLaat, S.W., VanZoelen, E.J.J., Mitogenic stimulation of human breast cancer cells in a growth factor-defined medium: synergistic action of insulin and estrogen, J. Cell. Physiol., 134 (1988) 101.

29 Koenuma, M., Yamori, T., Tsuruo, T., Insulin and insulin-like growth factor I stimulate proliferation of metastic variants of colon carcinoma 26, Jpn. J. Cancer Res., 80 (1989) 51.

30 Recio-Pinto, E., Ishii, D.N., Effects of Insulin, Insulin-like Growth Factor-II and Nerve Growth Factor on Neurite Outgrowth in Cultured Human Neuroblastoma Cells, Brain Res., 302 (1984) 323-334.
31 Recio-Pinto, E., Ishii, D.N., Insulin and related growth factors: effects on the nervous system and mechanism for neurite growth and regeneration, Neurochem. Int., 12 (1988) $397-$ 414.

32 Luo, J., Murphy, L.J., Regulation of insulin-like growth factor binding protein- 3 expression by dexamethasone, Mol. Cell. Endocrinol., 74 (1990) 213-219.

33 Wang, C., Li, Y., Wible, B., Angelides, K.J., Ishii, D.N., Effects of insulin and insulin-like growth factors on neurofilament mRNA and tubulin mRNA content in human neuroblastoma SH-SY5Y cells, Mol. Brain Res., 13 (1992) 289300.

34 Fernyhough, P., Mill, J.F., Roberts, J.L., Ishii, D.N., Stabilization of tubulin mRNAs by insulin and insulin-like growth factor I during neurite formation, Mol. Brain Res., 6 (1989) $109-120$.

35 Morrison,R.S., deVellis,J., Preparation of a chemically defined medium for purified astrocytes. In D.W. Barnes, D.A. Sirbasku and G.H. Sato (Eds.), Methods for serum-free culture of neuronal and lymphoid cells, Alan R. Liss, Inc., New York, 1984, pp. 15-22.

36 Meghani, M.A., Martin, D.M., Singleton, J.R., Feldman, E.L. (1993) unpublished data.

37 Martin, D.M., Feldman, E.L., Reversibility of serum removal effects on IGF-II mRNA in human neuroblastoma cells, Proc NY Acad. Sci., (1993), in press.

38 Martin, D.M., Carlson, R.O., Feldman, E.L., Interferon- $\gamma$ inhibits DNA synthesis and IGF-II gene expression in human neuroblastoma cells, J. Neurosci. Res., 34 (1993) 489-501.

39 Ota, A., Shen-Orr, Z., Roberts, C.T.,Jr., LeRoith, D., TPAinduced neurite formation in a neuroblastoma cell line ( $\mathrm{SH}$ SY5Y) is associated with increased IGF-I receptor mRNA and binding, Mol. Brain Res., 6 (1989) 69-76.

40 Påhlman, S., Meyerson, G., Lindgren, E., Schalling, M., Johansson, I., Insulin-like growth factor I shifts from promoting cell division to potentiating maturation during neuronal differentiation, Proc. Natl. Acad. Sci. USA, 88 (1991) 9994-9998.

41 Rosenthal, S.M., Brown, E.J., Brunetti, A., Goldfine, I.D., Fibroblast growth factor inhibits insulin-like growth factor-II (IGF-II) gene expression and increases IGF-I receptor abundance in BC3H-1 muscle cells, Mol. Endocrinol., 5 (1991) 678-684.

42 Bondy, C.A., Werner, H., Roberts, C.T. Jr., LeRoith, D., Cellular pattern of insulin-like growth factor-I (IGF-I) and type I IGF receptor gene expression in early organogenesis: comparison with IGF-II gene expression, Mol. Endocrinol., 4 (1990) 1386-1398. 